\title{
Japanese industry wakes up to computer networking
}

Tokyo. A small, privately funded research institute is pioneering the use of international data networks in the social sciences, and in particular has become the first Japanese social science research organization to subscribe to Internet, the international network of networks.

The institute is gathering support at a time when both Japanese government and industry are showing a sudden interest in computer-based communications. The main factor leading to this shift in emphasis appears to have been the aggressive approach of the Clinton administration to networking in the United States, making it possible, for example, to download electronic publications directly from the White House.

Such a level of accessibility astonishes most Japanese. US policy has galvanized officials at the Ministry of Posts and Telecommunications into frenzied discussions on how to go about networking Japan. Their fear is that, if they fail to come up with an appropriately positive response to the Clinton initiative, they will be criticized for holding back the country's economic development.

The National Institute for Research Advancement by the Centre for Global Communications (Glocom) was founded three years ago as an offshoot of a graduate school called the International University of Japan. Although it has only five full-time researchers, the institute has already shown that it has the potential to play a key role in Japan's struggle to come to terms with information revolution.

The Japanese scientific community in general has been very slow to adopt computer networking (see Nature 363, 575; 1993). In university social science departments in particular, network connections are still virtually unknown.

But the rapid increase in the global significance of this new technology has already been illustrated by an international survey of policy research organizations carried out by Glocom itself and released at the end of August.

That survey showed that 51 per cent of such organizations already use electronic mail, that almost a third are connected to Internet, and that the rate of connection is increasing exponentially over time.

Izumi Aizu, Glocom's managing director, says that the institute wants to become a gateway through which Japanese social scientists and policy researchers can make their opinions and papers known - at nominal cost - to the outside world.

In particular, he says, publishing such work electronically through Internet will encourage interaction between Japanese researchers and their counterparts in other countries. Thus, rather than being presented with the finished product, the rest of the world should be able to get some idea of what projects Japan has in the pipeline, as well as the opportunity to contribute to them.

At the same time, Glocom has also embarked on a campaign to promote connection to Internet in Japan. At present, Aizu points out, Internet is not widely used. The main obstacle is expense: the leased lines required for connection to the network cost at least five times more in Japan than they do in the United States. Other barriers include restrictions on the type of institutions which are allowed to use the network, and the inevitable barrier caused by language differences.

Unusually for Japan, Glocom has decided not to apply for government aid. "We don't have time to do the paperwork," says Shumpei Kumon, the centre's acting director and a former professor of international relations at the University of Tokyo.

Kumon's previous position gave him first-hand experience of the red tape involved in education ministry grants. In contrast, Glocom's annual funding of approximately $¥ 100$ million $(\$ 950,000)$ comes almost entirely from private companies, including in particular Nippon Telegraph \& Telephone (NTT), Tokyo Electric Power Co., and the department store group Saison.

The support received from these sources is in line with Kumon's prediction that while science has prospered from government support in the past, the role of government will in future diminish, and an increasing amount of funding for research will come from the private sector.

The companies that fund Glocom appear to have been motivated by an awareness that success in business depends increasingly on

\section{Grant winners get a surprise bonus}

Munich. Scientists in the German state of Baden-Württemberg who receive support from the Deutsche Forschungsgemeinschaft (DFG), Germany's main source of funding for university research, are due for a pleasant surprise. The local state government has decided to introduce a bonus scheme under which all new DFG grant holders will have the money they receive topped up by a further five per cent.

Baden-Württemberg contains a number of major research centres including Heidelberg, Freiburg and Stuttgart. The bonus scheme is intended to preserve its status as a 'high-tech' state; research minis-

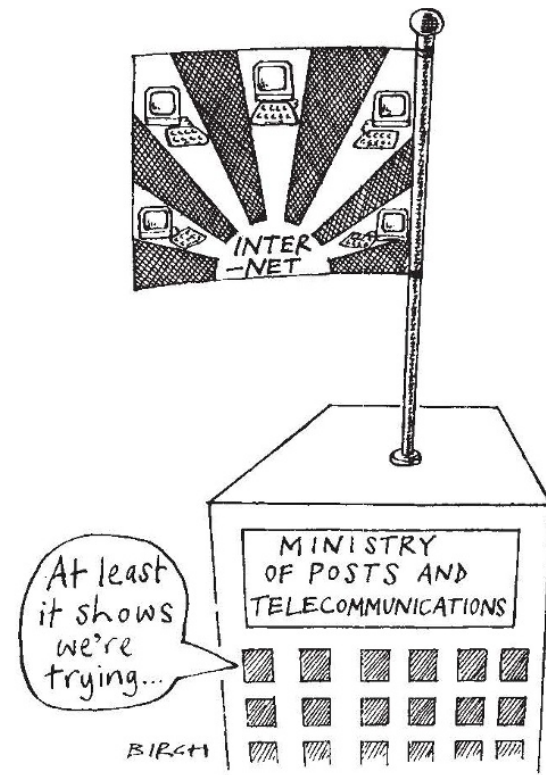

how companies handle information. They are encouraged to participate in the centre's research rather than just donating money.

Kumon himself sees this in a broader perspective, and talks of establishing a new, all-encompassing branch of social science that will provide an intellectual framework for mapping the landscape of an increasingly information-oriented society.

Such ideas may sound grandiose. But Japanese businessmen and politicians seem to be listening. Last year, for example, the telecommunications company NTT turned down a proposal from Glocom for a joint project to study the potential of computerbased communications. This year, the company says it is more interested.

Bob Johnstone

William Waldegrave, Britain's cabinet minister responsible for science, is to pay a four-day visit to Japan at the end of September. Waldegrave plans to visit Tsukuba Science City, as well as a secondary school science class, and to hold discussions with leading scientists.

ter Klaus von Trotha hopes it will encourage university scientists to increase their efforts to seek external funding, rather than merely relying on that provided through the universities' own budget.

At present the scheme, which will be backdated to the beginning of this year, will run only up to the end of 1994. But von Trotha hopes it will be extended beyond this date, and also that it will be expanded to cover research grants obtained from other external sources. Last year universities in Baden-Württemberg attracted about DM550 million (\$344 million) of external funding.

Alison Abbott 